\title{
CACHORROS QUE ATACAM CRIAÇÃO: REFLEXÕES ÉTICAS SOBRE A MOBILIDADE E A VIDA SOCIAL DOS ANIMAIS EM AMBIENTES RURAIS
}

\author{
Jorge Luan Teixeira ${ }^{1}$ \\ Dibe Ayoub ${ }^{2}$
}

\begin{abstract}
Baleia queria dormir. Acordaria feliz, num mundo cheio de preás. E lamberia as mãos de Fabiano, um Fabiano enorme. As crianças se espojariam com ela, rolariam com ela num pátio enorme, num chiqueiro enorme. $\mathrm{O}$ mundo ficaria todo cheio de preás, gordos, enormes.(Graciliano Ramos, "Vidas Secas")
\end{abstract}

Em nossas diferentes pesquisas, percebemos problemas similares enfrentados pelas coletividades com que trabalhamos, os quais dizem respeito aos cachorros que atacam rebanhos. Enquanto Jorge Luan Teixeira (2014) observa essa questão em áreas rurais do município de Catarina, localizado no Sertão dos Inhamuns, Ceará, Dibe Ayoub (2016) o faz em faxinais do município de Pinhão, Paraná. Tratam-se, evidentemente, de localidades e sujeitos distintos. Contudo, possuem algo em comum: em ambos os casos, os modos de vida e as práticas cotidianas de nossos interlocutores caracterizam-se pela primazia dada à criação de animais. Os cachorros, por sua vez, também fazem parte dessas socialidades, participando da vida doméstica, do cuidado da casa e do gado, e auxiliando alguns moradores nas atividades de caça. Ora bons companheiros, ora terríveis predadores, eles possuem um estatuto ambíguo, podendo ser amigos ou rivais, tais como vizinhos também o são.

Ao longo de nossos trabalhos de campo, nós nos defrontamos com situações de morte de animais de criação em virtude de ataques caninos. Frente a isso, nossos interlocutores, lesados pelos cachorros, mostravam-se inconformados. A solução que apontavam era matar os cães que protagonizaram tais ataques. Porém, logo percebemos, tal resposta não era desprovida de justificativas, avaliações e considerações a respeito dos bichos e de seus donos. São justamente tais problematizações sobre o que fazer e como lidar com humanos e animais que pretendemos abordar ao longo deste texto, com o objetivo mais amplo de refletirmos sobre a produção de relações e reputações em comunidades morais interespecíficas.

\footnotetext{
${ }^{1}$ Universidade Estadual Vale do Acaraú, Brasil.

2 Universidade Federal do Rio de Janeiro, Brasil.
} 
Os moradores de Pinhão chamam de faxinal $^{3}$ as áreas caracterizadas pela presença da floresta de araucárias, as quais foram historicamente constituídas como terras de uso comum para a criação de animais, sobretudo de gado bovino e suíno. Ao longo da segunda metade do século passado, com a tomada de muitas terras do município por uma empresa madeireira e a compra de terrenos por pessoas que exerciam modos mais particularistas de apropriação e uso do território, grande parte das terras de uso comum foi reconfigurada, e as cercas que demarcam os terrenos de famílias específicas se tornaram uma constante nessa paisagem onde antigamente o gado caminhava livremente por toda a parte. Ainda assim, a criação permanece, junto com o extrativismo de erva-mate, como a principal atividade produtiva de quem vive nos faxinais. No caso da família Miller, a partir de cujas experiências discutimos os ataques de cães em Pinhão, os animais de criação presentes no terreno familiar são o gado bovino, suíno, ovino e caprino, sendo estes três últimos os mais vulneráveis às investidas caninas.

Em Catarina, por sua vez, a criação de animais é central para grandes e pequenos proprietários. Em algumas dessas propriedades rurais podem viver moradores e vaqueiros - famílias de trabalhadores que, resumidamente, recebem uma casa de morada em contrapartida aos serviços prestados aos donos das propriedades, além de pagamento pelos serviços realizados para eles. Vivendo na terra dos outros, muitos moradores têm permissão de criar animais para além das aves domésticas, que habitam os quintais da maioria das casas sertanejas. Alguns moradores são vaqueiros, ligando-se aos proprietários de forma diferenciada. Ao tomarem conta da criação de seus patrões majoritariamente rebanhos de bovinos, caprinos e ovinos -, os vaqueiros acumulam uma renda maior do que aquela dos outros moradores, que, em geral, se dedicam apenas à agricultura.

Se é possível observarmos a atividade de criar animais como fundamental à organização da propriedade e da economia familiar camponesa, as experiências de nossos interlocutores demonstram que, para além dos aspectos referentes à produção agropecuária, os animais de criação são tomados como parte de certas terras e de certos donos, compartilhando de formas específicas a vida social nessas localidades. De fato, a relação entre humanos e animais de criação vem ganhando destaque, nos últimos anos,

\footnotetext{
${ }^{3}$ Ressaltamos que, para fins de organização textual, utilizamos o itálico sempre que nos referimos aos termos e frases de nossos interlocutores (exceto em citações mais longas, deslocadas em parágrafos específicos no texto). As citações de categorias teóricas, autores e termos do senso comum acadêmico estão colocadas entre aspas.
} 
em etnografias e artigos que versam sobre ruralidades no Brasil. Seja por via da afetividade entre criadores e o gado (Andriolli, 2011), da caça aos predadores que ameaçam os rebanhos e das concepções nativas sobre eles (Sussekind, 2014), da circulação dos bichos pela terra (Pereira, 2015), ou da produção de parentesco entre criadores e reses (Leal, 2014), todos esses trabalhos chamam atenção para as influências mútuas entre seres humanos e bichos.

Nos Inhamuns e em Pinhão, os animais que costumamos chamar de "domésticos", como os cachorros, também são relacionados a seus donos e integrados à vizinhança, perambulando por dentro das cercas que delimitam os terrenos e passando para fora delas. Assim, na socialidade dos faxinais de Pinhão e dos moradores do Sertão dos Inhamuns, os animais tidos como “de alguém” possuem uma face pública, a qual diz respeito aos seus comportamentos e atos e abrange sua identificação com seus donos, famílias e com terrenos específicos. Além disso, suas ações são matéria de atenção e interesse contínuo de seus donos e da vizinhança mais ampla, o que os torna parte da ética da vida cotidiana, estando sujeitos a avaliações e problematizações sobre o que é bom ou ruim, certo ou errado, justificável ou incompreensível, e sobre o que fazer (e como fazê-lo) frente a tais ações.

Inspirados na noção de "ética ordinária” (Lambek, 2010; 2015), compreendemos a ética como imanente às ações, aos julgamentos e às reflexões cotidianas, e não como um domínio social específico ou uma esfera de questões transcendentais. Não se trata, portanto, de uma leitura normativa, focada em regras ou obrigações que possam ser seguidas ou quebradas, mas de uma orientação que considera "múltiplos critérios, compromissos diversos e valores incomensuráveis" (Lambek, 2015: 7). É frente a tais critérios, compromissos e valores, mas também ao fluxo contínuo da vida social, que um certo "julgamento prático" é executado. Ao irmos além da normatividade, como sugerem Foucault (2010) e Laidlaw (2002; 2014), incluímos a liberdade como dimensão central da vida social e da constituição das pessoas e de suas ações no mundo.

Essas considerações sobre ética constituem para nós um importante ponto de partida, pois as maneiras com que as pessoas realizam e questionam as formas supostamente apropriadas de agir e de viver com os outros são cruciais nas experiências envolvendo os ataques de cachorros à criação. Intentamos, assim, observar as disciplinas mais corriqueiras que as pessoas desenvolvem e performatizam em seus cotidianos, como expressões da ética (Das, 2012). Pois para os sujeitos com quem trabalhamos, os animais de criação e os cães são seres fundamentais para a conformação 
do bom convívio entre familiares e vizinhos, o qual é feito, desfeito e refeito cotidianamente, através de atos como os cumprimentos, as visitas, as caronas, as trocas de alimentos e de várias modalidades de ajuda, entre tantas outras práticas, como aquelas que envolvem a observação e o cuidado com a circulação dos bichos pela vizinhança.

Buscamos aqui esboçar uma espécie de ética comparada do pastoreio, tomando como ponto de partida não categorias "universais" ou comuns, mas sim as próprias ações dos nossos interlocutores, as práticas pelas quais eles lidam com os ataques dos cães. O objetivo desse exercício de comparação é que um contexto etnográfico ilumine o outro, a fim de delinearmos questões que nos ajudem a compreender essas socialidades rurais nas quais os animais ocupam um lugar fundamental. Salientamos, assim, a centralidade que a mobilidade de animais e humanos ocupa nas atividades mais corriqueiras dos moradores das localidades onde realizamos nossos trabalhos. Com essas movimentações ocorrem também a circulação de histórias e de narrativas que envolvem e produzem conhecimentos sobre animais, famílias e terras, enquanto problematizam modos apropriados ou desagradáveis de se viver com os outros. Na primeira parte do texto, analisamos como os Miller de Pinhão encontram seus próprios meios de lidar com os cães alheios que adentram suas terras e matam sua criação. Na segunda parte, o foco é dado aos moradores de Catarina e suas narrativas sobre o vício dos cães e as atitudes humanas frente aos ataques caninos. Elaboramos, em seguida, uma discussão mais ampla sobre as reflexões éticas de nossos interlocutores, buscando pensar como o cuidado de si e dos outros é exercido nessas relações e interações interespecíficas.

\section{Naturezas éticas: os cães que atacam criação no faxinal}

Os carreiros, trilhas de passagem que atravessam as terras da família Miller, em Pinhão, Paraná, são caminhos por dentro de um mato frondoso, composto por inúmeros pinheiros, imbuias, canelas, e outras espécies que compõem a mata de araucárias. Ali, abundam também os pés de erva-mate, cujo extrativismo é fundamental para a economia dos membros desse coletivo familiar. As terras da família são delimitadas, em sua face mais baixa, pelo Rio Bonito, que ali despenca em uma cachoeira e depois segue seu curso em um vale que se estende por quilômetros. O relevo, logo se vê, é acidentado, com sobes e desces entre o mato e um grande declive rumo ao Bonito. 
Os Miller habitam um terreno familiar de quarenta alqueires. O terreno é "familiar" porque é identificado com uma família (os Miller) e também porque é dividido entre membros desse coletivo: Seu Benedito Miller, casado com Dona Lúcia Miller, Abel, filho mais velho do casal, e Vitório, nascido depois de Abel. Seu Benedito, Abel e Vitório, portanto, são donos de pedaços específicos do terreno, nos quais têm suas casas, onde vivem com suas esposas e filhos. É somente em suas próprias porções de terra que cada dono extrai erva-mate. Porém, a criação de gado, porcos, carneiros e cabritos ultrapassa as áreas vinculadas aos seus donos específicos, caminhando por todo o terreno familiar, cujas divisões internas não são demarcadas por cercas. Conforma-se, nesse caso, uma lógica de ocupação e uso do território relacionada aos modos com que os faxinais se constituíram historicamente em Pinhão: terras de uso coletivo para a criação de animais, mas caracterizadas também por formas mais "privadas" de exploração, como ocorre com o extrativismo de erva-mate ${ }^{4}$. Além disso, no caso dos Miller e de tantos outros moradores do interior pinhãoense, há uma sobreposição entre o terreno familiar e terrenos internos a ele, tidos como particulares a determinados membros da família.

Os animais de criação passam o dia a dar sua volteada pelo terreno. Carneiros, cabritos e o gado bovino fazem diariamente os mesmos trajetos em busca de alimento entre o mato e nas áreas mais próximas às casas, as quais são tidas como mais limpas, das quais o mato, alto e denso, foi retirado para dar lugar a gramíneas. Nos pontos mais baixos do terreno, na beira do Bonito, Abel faz o pasto onde deixa o gado bovino durante o inverno. Por entre o mato e perto das casas circulam também porcos e porcas, estas geralmente acompanhadas de uma ninhada de leitõezinhos, todos num fuçar incessante, revirando o solo em busca de alimento. O porco, dizem os pinhãoenses, é um bicho andejo. Não há cerca que não atravessem em seu caminhar insistente. Por isso

\footnotetext{
${ }^{4}$ Faxinal é o nome com que os moradores de Pinhão nomeiam as áreas de mata de araucária, nas quais as atividades produtivas giram majoritariamente em torno da criação de gado e do extrativismo de ervamate. As terras situadas em encostas de serras e nas beiras de rio são, por sua vez, chamadas de terras de cultura, locais onde os moradores dos faxinais realizam sazonalmente o plantio e a colheita de lavouras, ou onde há moradores permanentes exercendo tais atividades. Nos últimos anos, houve mudanças nessas formas de apropriação e uso do terreno, de modo que, em alguns locais do município, os moradores relatam que hoje os faxinais estão sendo povoados pelas culturas, enquanto o gado tem sido levado pra baixo, perto dos rios, cujas beiras têm se tornado áreas de pastagens. Além disso, os modos tradicionais de ser e de viver dos habitantes dos faxinais paranaenses são centrais para diversas coletividades que buscam seu direito à terra, identificando-se nesse processo como faxinalenses e constituindo-se em movimento social. Em Pinhão, há duas comunidades faxinalenses, reconhecidas pelo Estado do Paraná como Áreas Especiais de Uso Regulamentado (ARESURs), territórios coletivos caracterizados pela criação de gado à solta e em áreas de uso comum, tal como os faxinais se constituíram historicamente. Não é esse o caso do faxinal onde vivem os Miller. Para mais sobre faxinais, ver Chang (1988), Almeida \& Souza (2009), Souza (2010), Porto (2013).
} 
mesmo os Miller frequentemente se viam às voltas com reclamações de vizinhos, atormentados pelos porcos que haviam ido parar dentro de suas terras e andavam comendo suas hortas e mandiocais. De sua parte, os Miller também tinham seus tormentos com os bichos alheios; mas, em seu caso, os cachorros é que eram o problema.

“Criação dá muita bronca", disse certa vez Dona Francisca, também moradora de uma área de faxinal, quando contava sobre sua desistência de criar porcos. Ela havia cansado de ver os outros matarem seus bichos, que não resistiam ao atravessamento das cercas e iam "incomodar nos vizinhos", os quais acabavam carneando, ou seja, abatendo e transformando em carne os porcos que apareciam em seus terrenos. Para além de histórias de pessoas carneando porcos intrometidos, há também casos de vizinhos que brigam uns com os outros por causa dos estragos causados por esses animais. No calor das broncas, discussões onde ofensas são trocadas, não é incomum acontecerem ameaças e agressões físicas mais sérias.

Os Miller se aborreciam muito com as queixas dos vizinhos e vizinhas, uma das quais chegou a insinuar que denunciaria um dos membros da família à polícia por causa de uma porca que havia arruinado seu mandiocal. O drama chegou a tal ponto que os porcos começaram a ser fechados em chiqueiros e carneados. O plano era acabar com aquela criação específica, algo que deixava Dona Lúcia bastante desgostosa - era, de fato, a prática de uma vida inteira que ali se encerrava - e dava um certo alívio a Abel, pois eram ele e sua esposa, Ângela, os que mais ouviam as broncas dos vizinhos.

Os porcos e as broncas que os envolvem são exemplos de como a mobilidade dos animais pode levar vizinhos a graves desentendimentos e de como os donos e os bichos se veem enveredados em tramas nas quais os limites territoriais e a liberdade de ação e circulação são encadeados de tal modo que humanos e animais são considerados como partes uns dos outros. Assim, as broncas e avaliações que decorrem de situações em que bichos causam algum tipo de dano deixam à mostra uma socialidade da qual participam vizinhos não somente enquanto membros de famílias formadas por humanos, mas também enquanto pessoas que possuem animais e que são vinculadas a um determinado terreno, um espaço que é tido como o seu e no qual são autônomas na realização de suas atividades. Os animais, em contrapartida, são reconhecidos não só pelas particularidades de suas espécies, mas também como seres vinculados a certos donos, famílias e terras. 
Incomodativos para alguns, os bichos são também queridos por seus donos, os quais muitas vezes não admitem que sua criação ou seus cães sejam atacados por outros animais ou por humanos. E se os porcos eram um incômodo que os vizinhos vinculam aos Miller, os cachorros eram uma tribulação que os Miller localizavam nos vizinhos. Ou seja, os cães de fora eram o problema. Os deles próprios, mantidos por perto, jamais foram considerados uma ameaça à criação. Tanto Dona Lúcia quanto Abel salientam aquela que consideram uma qualidade fundamental em seus cães: eles acuam quando veem estranhos, avisando seus donos sobre a aproximação de pessoas ou de outros bichos. Para Dona Lúcia e Abel, seus cães são agentes que cuidam da casa.

Os cães dos Miller só são tidos como bons e aceitos nas casas e terras da família porque jamais demonstraram o gosto por pular na criação. Em certo momento, Ângela salientou que "cachorro e criação junto não dá certo", ainda que no terreno familiar houvesse três cães. Esse ditado foi enunciado no decorrer de uma situação de morte de criação em virtude de ataques de cachorros de fora, os quais haviam entrado no terreno familiar.

No dia em que Ângela anunciou essa prerrogativa, Abel havia contado a criação e dado por falta de dois cabritos e uma carneira. Saiu para campear os bichos no mato e no caminho encontrou rastros de cachorro. Frente a isso, ele voltou para casa, pegou a espingarda e saiu novamente para procurar a criação perdida e os cães. Quando retornou, disse que havia encontrado um bando de cachorros e que conseguira atirar em dois. Além disso, ele havia achado a carneira e os cabritos que estavam faltando, os quais, como suspeitara, haviam sido mortos pelas mordidas dos cães.

Enquanto Abel estava procurando os cachorros e a criação, Ângela permaneceu em casa. Ao contar sobre o que acontecia, ela cogitava a possibilidade de os cachorros terem vindo do outro lado do Rio Bonito, que não é difícil de atravessar e dá acesso ao terreno dos Miller. Ângela acreditava que eles eram caçadores, ou seja, treinados por seus donos a caçar e a auxiliá-los em tal atividade. Ensinados a atacar outros animais selvagens, como veados, os cachorros acabavam pulando na criação quando a encontravam. E se durante as saídas para caçar eles passavam por terrenos alheios junto com seus donos, os cães também entravam nas terras dos Miller por conta própria. Ângela comentou, então, que os cachorros caçadores viviam na corrente, presos e mal alimentados. Quando soltos, eles saíam a caminhar em busca de comida e, inevitavelmente, acabavam atacando a criação. 
Uma vez que o cachorro aprende a pular nos outros animais, disse Ângela, não há o que faça ele parar. É preciso matar o cão. Porém, quando referiu-se aos cães caçadores, ela comentou que "aí dá dó de matar o bicho, pois ele foi ensinado pra fazer assim". Ângela diferenciava, nesse sentido, o "pular na criação" enquanto característica própria da natureza do cachorro, que instintivamente ataca e come outros animais, e enquanto algo ensinado por seu dono, que para caçar utiliza o cão.

Natureza é um dos termos que os moradores do interior de Pinhão usam para falar dos comportamentos e personalidades que humanos e animais expressam. $\mathrm{O}$ corpo, enquanto composição que comunica moralidades, é o local onde a natureza se manifesta, sendo assim tema de avaliação. Alguns humanos são tidos como trabalhadores incansáveis, que não param de realizar tarefas na casa e na terra, algo de sua natureza. Outros sabem lidar com calma com os demais humanos, mesmo quando estes demonstram raiva ou descontrole. Outros são bravos de tal modo que não dá nem para chegar perto. É sua própria natureza que faz os seres mais propensos a certas atitudes, as quais se tornam esperadas, tendo em vista a continuidade de tais condutas. Natureza, por conseguinte, é algo fundamental para a produção de "reputações", opiniões que as pessoas fazem umas das outras levando em consideração sua performance ao longo de interações (Bailey, 1971) e que estão sendo permanentemente renegociadas e redefinidas no interior das relações, ainda que também influenciem o andamento dessas relações (Marques, 2002).

No caso dos bichos, especificamente, a natureza é compreendida como algo peculiar ao seu modo de ser enquanto espécie, embora também possa remeter à forma de ser dos bichos tomados em particular, como seres que desenvolvem certos modos de agir e de estar entre humanos e outros animais. Assim, é da natureza do porco ser andejo, enquanto os cachorros têm uma natureza que os leva a pular na criação. Contudo, se os porcos criados à solta pelo terreno são tomados em geral como atravessadores de cercas, os cachorros apresentam algumas diferenças, na medida em que a natureza que contêm não determina que todos eles venham a atacar outros bichos. Desse modo, natureza não é um termo que corresponde necessariamente a um instinto fundante e inevitável que os animais possuem dentro de si, ainda que em certos momentos possa adquirir essa conotação. Natureza, tal qual os moradores do interior pinhãoense a problematizam, não é um domínio normativo, mas algo que podemos aproximar à ideia de "substância ética" (Foucault, 2010), à maneira enquanto uma parte de si mesmo é destacada como matéria principal da conduta moral, cultivada, no caso 
dos cães, não somente na relação deles com o próprio corpo e instinto, mas também nas relações com seu dono e família, com outros animais, com a casa e com a vizinhança. A natureza, portanto, não é um código que precede a prática, mas algo que se torna motivo de atenção na medida em que se materializa em ato.

No que diz respeito aos cães, essa conformação da natureza enquanto algo relacional é bastante clara nas narrativas dos Miller sobre os ataques à criação, momentos em que eles mesmos colocavam em cena sua avaliação do ocorrido e dos agentes ali envolvidos. Se em certo momento Ângela havia comentado sobre a impossibilidade de um cachorro e a criação "darem certo" juntos, por outro lado, ela e Abel também diziam que os cães que haviam matado os carneiros eram caçadores, alcunha que remete às práticas de caça exercidas por seus donos, que os haviam treinado para pegarem outros bichos. O casal considerava que o cachorro é passível de ser ensinado pelos humanos, e esse ensinamento tanto pode direcioná-lo a avançar em outros seres quanto levá-lo a um convívio tranquilo com eles. O cão que ataca uma criação, mesmo depois de ter sido ensinado a não fazê-lo ou por sua própria vontade, é chamado de "sem-vergonha", sendo a "sem-vergonhice" algo considerado de sua natureza, nem sempre domesticável pelos humanos. Porém, os cães caçadores, aqueles cujos donos os treinaram para perseguirem outros bichos, são avaliados de outra maneira. Nesse caso, suas ações são diretamente vinculadas aos seus donos, que incentivam os cães a desenvolverem tais comportamentos. A ação do humano e a do cachorro, desse modo, são consideradas conjuntamente. E por essa via não é mais o cão o "sem-vergonha", e sim o dono que o ensinou e que o deixa livre para causar estragos às criações dos outros.

Os animais que atravessam cercas e ocasionam prejuízos em terras alheias são tidos como causadores de danos. No dia em que Abel estava em busca dos cachorros que haviam matado a criação, Ângela ressaltou que de nada adiantaria ir atrás do dono dos cães para explicar o ocorrido e tentar fazer um acordo com ele. "Eles não pagam o dano", ela dizia. Pagar o dano, em termos ideais, é indenizar a pessoa lesada, quitando em dinheiro o valor da criação morta. Embora se considere a possibilidade de chamar na delegacia o dono de um animal que causa danos, tal ação não costuma se realizar. Ao invés de chegar-se a uma conciliação entre as partes por meio da mediação do delegado e do pagamento de dinheiro, o criador que teve seus bichos mortos busca, com seus próprios meios, matar os cães de fora que adentram suas terras. 
Abel e Ângela passaram por momentos dramáticos envolvendo a matança de criação. Foram tantas mortes que o rebanho de quarenta e sete cabritos chegou a nove. A princípio, quando perguntados sobre o que havia acontecido com os animais, Dona Lúcia e Abel diziam que "o bicho pegou". Questionados sobre que bicho era esse que matava tanta criação, eles respondiam "de certo um bicho que vive no mato". Foi somente depois de um tempo que tornou-se claro que o bicho eram cachorros de outras pessoas.

Numa das vezes, cachorros alheios mataram doze carneiros de uma vez só. Era carneiro morto por toda a parte no mato e perto do Rio Bonito. Em outra ocasião, Ângela encontrou cerca de dez cabritos mortos na beira do pequeno rio que passa perto de sua casa. Ela se sentou no chão e chorou, desesperada, vendo em volta de si aquele monte de cadáveres de cabritos. No mesmo dia, Artur, irmão de Abel que estava de visita na casa de Dona Lúcia, pegou os dois cachorros que estavam atacando as criações. Conseguiu matá-los. Suas donas, Neide e Palmira, duas mulheres da vizinhança, vieram reclamar. Bravas, as mulheres diziam que aquilo não era culpa dos seus cães, que Artur não precisava ter matado os bichos. Palmira, em especial, era muito apegada ao seu cachorro, que cuidava da casa para ela. Mas Artur disse que não teve como deixar passar, pois havia visto os dois bichos em cima dos cabritos. As mulheres não puderam protestar frente a isso. Elas também não teriam condições de pagar $o$ dano, imenso.

Portanto, não eram só cães caçadores que entravam no terreno dos Miller e atacavam a criação, mas também outros cachorros da vizinhança. A situação envolvendo os cabritos e os cães de Neide e Palmira revela a tensão contida no ato de matar um cachorro alheio, mesmo após um grande dano. Apegados aos seus bichos, os donos dos cães não admitem esse tipo de solução fatídica e discussões mais sérias podem ocorrer, ainda mais se a pessoa lesada e o dono do cachorro forem afeitos a broncas e brigas. Por outro lado, recorrer à solução do pagamento pelo dano sofrido também não é algo simples, pois envolve o acionamento do delegado e um processo jurídico formal, e nada garante que seu desfecho agrade à pessoa que sofreu a perda de criação (e, no caso dos Miller, eram perdas muitas vezes impagáveis, devido à quantidade de animais mortos).

Cachorro que é pego matando criação tem que ser morto. Essa é uma máxima reconhecida pelos moradores do interior de Pinhão, ainda que alguns possam querer argumentar contra ela quando o cão em questão é o seu. "Não carecia matar o bicho", 
diriam os donos apegados e tristes. E assim, a pessoa que sofreu perdas com os ataques caninos pode acabar se passando por alguém que fez algo ruim ou entrando em conflitos que podem se tornar grandes inimizades.

Levando em conta as angústias envolvidas nessas situações de matança de criação e de busca por punição aos cães responsáveis, as pessoas evitam comentar tais acontecimentos com seus vizinhos. Entre os Miller, essa discrição se expressava na expressão "o bicho pegou", por meio da qual afirma-se que foi um animal que matou a criação, mas não se explicita nada a seu respeito. Na maior parte das vezes, o bicho são cachorros, que podem ser dos vizinhos, sejam eles de longe ou do outro lado do rio, caçadores ou "sem-vergonhas". Não definir o bicho, contudo, é uma forma de não identificar o animal e, consequentemente, seu dono. Assim, pode-se perseguir o cão sem causar alarde na vizinhança.

Para descobrir e perseguir os cachorros, Abel ouve o barulho deles e observa seus rastros. É andando pelas terras de sua família e observando seus vizinhos que Abel pode vir a saber de onde vêm os cães que adentram seu terreno. Ele grava a figura do bicho e, ao ir às casas dos outros ou ao ver os cães acompanhando seus donos, identifica tanto os cachorros quanto o humano, a família e o lugar aos quais ele é vinculado. Porém, nem sempre há resposta precisa acerca de qual cão matou a criação, pois muitas vezes não se vê efetivamente o ataque aos outros animais, mas sim os bichos já mortos. Também por isso o dono de terras que sai à cata dos cães que estão causando danos é discreto e tenta matar os cachorros dentro de seu próprio terreno. Em geral, a morte do cão é dada com um tiro de uma arma silenciosa ou por meio de iscas envenenadas deixadas no mato. É importante matar e enterrar o cachorro ali mesmo, para evitar que os vizinhos espalhem o assunto e que haja qualquer discussão com o dono do bicho ou com outros moradores próximos, que podem não gostar de ter alguém na vizinhança matando os cães que passam por seu terreno. Pois quase todo mundo tem cachorros e eles andam pelas terras dos outros.

Para os Miller, a lida com a criação era uma atividade que garantia a estabilidade da economia familiar e que consolidava seu laço com as terras que habitavam. Mais do que isso, criar animais exigia uma série de cuidados por meio dos quais a família desenvolvia sua afetividade para com a criação e imbricava-se aos seus bichos. Era por prejudicarem a vida de seus animais que Abel se ressentia com os cachorros e seus donos, vizinhos. E era no terreno dele que sua luta contra esses animais e seus donos era travada. "Dá dó do bicho né, pois ele é inocente, não faz pra me prejudicar" - disse 
Abel, que como Ângela, refletia sobre a intencionalidade dos atos dos cachorros em relação com os humanos. A morte de um cachorro, assim, não se faz sem reflexão, o que a torna uma espécie de dilema em que são levados em conta a inocência dos cães, a inocência dos animais que eles matam e os afetos entre humanos que vivem perto e aos olhos uns dos outros. Solução convencional, o fim do cachorro não deixa de ser um possível início de outros problemas, estremecendo mais uma vez os vínculos entre vizinhos.

Nesse ponto, há uma convergência entre os atos de matar cães e porcos que causam danos: embora em conformidade a expectativas de agir certo, há maneiras mais ou menos apropriadas de realizar a morte e de falar sobre ela. Ainda que as pessoas levem em conta a possibilidade de se noticiar o dono do cão ou do porco sobre o dano ocorrido, essa ação não é tida como resolutiva, já que a ofensa não será paga e os animais seguirão causando estragos. Há quem crie bronca, ofendendo direta e publicamente o dono do bicho ou matando o animal e avisando o dono. Quem faz isso precisa assumir o risco de malquerença, já que nem todos são compreensivos perante as mortes dos seus animais, o que contrabalança a proposição de que matar é o certo. E por fim, é possível também matar o bicho e enterrá-lo, desaparecendo com uma história que sempre pode ser reativada, pois não há movimento isento de desconfianças nessa localidade onde todos vivem perto. Tal sumiço não é tão simples no caso do porco, que não é meramente morto, mas carneado, e sua carne é compartilhada entre famílias. $\mathrm{O}$ cão, porém, não se transforma em alimento. Ele é um ser da casa, da caça, do pastoreio, um ajudante e um companheiro próximo, um ser cuja morte é seguida de enterro.

\section{Os cachorros que pegam criação no Sertão dos Inhamuns}

No Sertão dos Inhamuns, grandes propriedades rurais coexistem ao lado de pequenos sítios tocados por uma mesma família ou parentela. Em algumas dessas propriedades, vivem moradores, trabalhadores rurais residentes que, não sendo donos de terra e nem da casa em que residem, ligam-se ao proprietário por meio de um "contrato de morada" (Palmeira, 1977), cujos termos e expectativas - informalmente estabelecidos, mas, em geral, tradicionalmente conhecidos - são variáveis: uma porcentagem da produção agrícola do morador deve ser paga ao patrão, o morador está à disposição da propriedade quando a sua força de trabalho (paga) for necessária, etc. Em Catarina, pequeno município dessa micro-região do Ceará, uma parte significativa 
dos proprietários são absenteístas, ficando a propriedade sob responsabilidade do(s) morador(es), que mantém comunicação regular com os patrões por meio dos telefones celulares.

Passado o auge da plantação de algodão - que trouxe grande riqueza para os sertões cearenses -, moradores, grandes e pequenos proprietários se voltam hoje, na maioria dos casos, aos cultivos do milho e do feijão. A semeadura de pastos com capim também se faz necessária para alimentar os gados bovino e ovino ${ }^{5}$. A criação semiextensiva de rebanhos bovino, caprino e ovino também ocupa, historicamente, papel fundamental na economia local (Chandler, 1980), havendo muitos moradores que são também vaqueiros. Muitos proprietários do município dizem ser a pecuária uma atividade econômica mais lucrativa do que a agricultura, não obstante as precipitações pluviométricas insuficientes e irregulares em alguns anos - são as secas (as estiagens), que, atualmente, se prolongam há cinco anos. Moradores e pequenos proprietários dizem o mesmo, sendo os rebanhos uma reserva de capital que lhes permite comprar uma motocicleta, um pequeno terreno ou realizar outros investimentos. A remuneração dos vaqueiros - ou mensal (um salário, inferior ao salário mínimo legal), ou na sorte, i.e., uma porcentagem (1/4 ou 1/5) dos animais nascidos -, significativamente maior do que aquela obtida na agricultura, é uma das razões que faz com que os moradores busquem essa posição.

Pedro Sobrinho é um desses vaqueiros. Alguns anos atrás, ele era encarregado dos rebanhos ovino e bovino da propriedade em que morava, o Sítio São Sebastião. O proprietário, vivendo em outro estado, pagava-lhe na sorte. O filho de Pedro, Mildo, morava em uma casa ao lado, sendo também vaqueiro, mas dos rebanhos de outro proprietário. Ambos têm cachorros, animais que, em geral, são considerados fundamentais para a segurança das casas. Os cães também são de grande serventia na luta com o gado, quando trabalham perseguindo e acuando os animais, o que facilita a ação dos vaqueiros, que devem reconduzir o gado fujão de volta ao rebanho e aos currais. Figuras fáceis nos terreiros e quintais das casas sertanejas, os cachorros estão com frequência rodeando seus donos e, comumente, são os primeiros a dar a notícia da chegada de alguém ou dos trânsitos na estrada. São também comuns os relatos sobre cachorros companheiros. Muito prezados, eles seguem seus donos e mesmo vizinhos às roças, aos açudes, etc, e de lá os acompanham de volta para suas casas.

\footnotetext{
${ }^{5}$ Enquanto o rebanho bovino é chamado de gado, os rebanhos ovino e caprino são chamados de criação.
} 
Como observado por alguns pesquisadores do campo da etnozoologia (Barboza, 2009; Alves, 2009), os cachorros são fundamentais na caça de vários animais da mastofauna sertaneja, sobretudo tatus (Dasypus novemcinctus), pebas (Euphractus sexcinctus), veados (Mazama gouazoubira) ${ }^{6}$ e onças (Puma concolor), talvez a maior ameaça aos rebanhos ovino e caprino. Para além de tais animais, eles ajudam a manter afastados de casa os tiús (Tupinambis merianae), lagartos que são uma ameaça às aves domésticas. As narrativas sobre as caçadas são repletas de comentários sobre as ações dos cachorros: de como perseguiram uma presa, de como se comunicaram perfeitamente com os humanos, de como conseguiram rastrear um animal por uma longa distância, de como detiveram um tatu ou peba sem mordê-lo e, assim, não arruinaram a sua carne, etc; mas também abundam comentários bem-humorados sobre o medo, a preguiça e os latidos desnecessários de alguns cães, que são ditos "ruins, não valem nada".

Se os cachorros são animais quase onipresentes no Sertão Cearense, se mais do que animais de estimação são animais de trabalho ${ }^{7}$, o seu estatuto moral é mais ambíguo do que se poderia supor: para além da agressividade, que pode ser direcionada a vizinhos ou a transeuntes, alguns deles são ditos viciados no sangue da criação, atacando-a. Se assim são descritos é pela expectativa da reincidência do ataque. $\mathrm{O}$ caso é similar com algumas onças, que se viciam no sangue da criação e causam grandes prejuízos a alguns proprietários em suas passagens ${ }^{8}$. Quando os cães se mostram viciados, eles trazem para o espaço da vizinhança uma "potência predatória" (Vander Velden, 2012: 303) que é mais associada às matas velhas e às serras, lugares em que os predadores felinos circulam. Se tal agressividade canina, dirigida a quem se julga que não deveria ser alvo dela, é algo que deve ser controlado ordinariamente de formas variadas, o caso do ataque à criação coloca problemas ainda mais delicados.

\footnotetext{
${ }^{6}$ Embora os cachorros possam sem empregados na perseguição aos veados, o mais comum é que, tendo rastreado a cama ou lugar onde o animal silvestre bebe água, o caçador faça uma espera, uma tocaia, próxima dali de modo a pastorar o veado e nele atirar. Em certa ocasião presenciada, após efetuar o disparo os cachorros foram usados para rastrear e perseguir o veado ferido.

${ }^{7}$ O próprio Pedro Sobrinho era motivo de deboche entre vizinhos seus por criar um cachorro já "caduco", muito velho e que mal se sustentava em pé. Dada a velhice do cão e a insistência do seu dono em mantêlo, um amigo da família dizia ser ele um bicho de estimação, marcando contrastivamente uma expectativa quanto à utilidade e à criação dos cães, a que o "cachorro caduco" não respondia mais.

${ }^{8} \mathrm{O}$ vocabulário moral do vício como forma de se referir à reincidência do ataque das onças também é usado por alguns pantaneiros (Sussekind, 2014: 96) - embora nesse caso se trate, fundamentalmente, da predação do rebanho bovino pela onça pintada (Panthera onca)-, que dizem ser ela uma ameaça aos negócios que precisa ser controlada.
} 
Certo dia, quando vaqueiro no Sítio São Sebastião, Pedro e o filho ouviram o latido de um cão no pasto em que as ovelhas estavam. Mildo reconheceu o latido: era o cachorro de Naldo, vaqueiro de uma propriedade vizinha e com quem ambos têm até hoje boas relações. Mais tarde, quando Pedro foi buscar a criação, se deparou com três delas mortas. Em diferentes investidas, treze ovelhas foram mortas, sendo algumas do patrão e outras do vaqueiro e da sua mulher. Ele ressalta que o cachorro não comia quase nada das ovelhas que matava, só bebia o sangue. Ao se deparar com a cena de um dos ataques, ele percebeu que um rastro de botas acompanhava as pegadas do cachorro, o que o fez afirmar que o dono estava por perto quando houve o ataque. Um dia, enquanto pastorava os cachorros, ele se deparou com Naldo, que citou o número de cabeças mortas. A precisão confirmou as suspeitas de Pedro - como o vizinho sabia do que poucos fora da família sabiam? -, que, então, insinuou a Naldo saber a verdade. Ao ser perguntado, anos depois, se o dono do cachorro havia reconhecido a culpa, Pedro, já morando em outro sítio, relembra a história:

\begin{abstract}
Se en-tre-gou naaaada... Se entregou foi porra! Ficou com a cara caída do dia que eu tava pastorando os cachorro que ele chegou e deu a quantidade que os cachorro tinham pegado. Ele se entregou-se porque eu falei: Mas agora ele vai demorar uns dias pra vir, aí ele disse, 'Por que?', digo, Porque o dono tava junto com ele ontem, ele matou duas ovelha grande na roça aqui e deixou duas marrãzinha ${ }^{9}$, eu achei elas, só não tavam morta, e tava o rastro do cara lá, e ali foi o cara que foi lá e tirou, correndo atrás dele gritando e tirou, porque ele matou duas ovelha daquele tamanho, [como] não matava duas marrãzinha daquela!? Rapaz, ele caiu a vista. Ali amarrou mesmo, meu amigo: ele ficou foi TRÊS MÊS amarrado! No dia que ele soltou, ele foi pro curral do Zezé... Acordou... O Zezé acordou-se pela Lúcia: 'Zezé, tem um cachorro no curral matando as ovelha'. Zezé meteu dos pés, macho, tinha matado qua-tro. Aí o Zezé... Saiu a notícia [...] Quando foi na outra noite, [os cachorros] desceu pro Bandeira, desceram pro Bandeira aí. Renato viu o rebuliço, levantou-se com a espingarda, derrubou um, o outro pulou na cerca, ele botou ele abaixo, o outro deu de ir embora. Aí ele foi bater lá e disse a ele, 'Rapaz, é o seguinte, um de seus cachorro eu matei e o outro você mata, senão cê vai pagar a criação'. Aí ele [Naldo] pegou e deu [a]o Patrício né? Aí, por lá, o Patrício deu [a] um cara lá pela rua. Marco ${ }^{10}$, ele deu um prejuízo medonho lá, Marco! Matou meio mundo de criação, mas aí os caba mataram ele. Cachorro horrível, macho!
\end{abstract}

Ao ser perguntado sobre Naldo e o caso do seu cachorro, Pedro narrou não só a insinuação que fez para o vizinho, mas também os fatos subsequentes que julgava relevantes para atestar, de um lado, a culpa do cachorro e, de outro, a fraqueza moral do seu dono, de forma que o "encumpridamento da história", como se diz, era um recurso narrativo com dupla finalidade. Se a culpa do cachorro era evidente, dado o histórico

\footnotetext{
${ }^{9}$ Uma ovelha que ainda "não deu cria", que nunca pariu.

${ }^{10} \mathrm{Um}$ vizinho que ali estava.
} 
dos seus ataques, a covardia de Naldo seria frisada adiante. Depois de repetir três vezes que teve "muita vontade de matar aquele cachorro", ele se justifica: "Por causa da covardia do fí duã égua. O cabra sabendo, macho, [que] o cachorro [estava] acabando a criação de um vizinho..." Ao ter consciência de que era o seu cão aquele que estava pegando a criação, o que se esperava era que Naldo assumisse a responsabilidade e resolvesse o problema.

Em parte, é o que Naldo fez ao ouvir a provocação de Pedro: amarrou o cachorro durante três meses em sua casa, mas bastou soltá-lo para que o animal, acompanhado de outro, pegasse quatro ovelhas de Zezé e, no dia seguinte, atacasse o rebanho de Renato, que, conhecendo-o previamente, teve como se dirigir a Naldo e provar a culpa do seu cachorro. Não só Renato o havia flagrado como matara outro dos cães. Se até então Naldo negava a culpa, não havia mais como fazê-lo. Os mesmos eventos, com um encadeamento narrativo similar, foram contados por um conhecido residente em um sítio próximo que não estava diretamente implicado no ocorrido, mas que o conhecia com riqueza de detalhes ${ }^{11}$ :

\begin{abstract}
Aí [o cachorro] veio aqui pro Zezé e pegou seis, os dois cachorro do dito Naldo. Aí Zezé foi lá: 'Não, rapaz, não é meu, não, esse cachorro não é meu, não'. Eles não vieram mais pra cá porque Zezé deu uns tiro e eles ficaram com medo, foram pegar lá no Renato. Quando chegou lá, não veio [voltou] os dois, não: só veio um. Renato flagrou, passou-lhe tiro num, ele ficou [morto] dentro do chiqueiro. Aí veio lá e disse: 'Naldo, os cachorro pegador de ovelha é os seus mermo', 'Nãm, cê viu?', 'Vi, que um eu matei, um tá morto lá dentro do meu chiqueiro, pegou duas criação minha, eu vim só lhe dizer, eu matei ele lá, e eu vim pra você matar o outro, ou então você vai pagar as criação', 'Não, rapaz, vamo fazer o seguinte, eu vou tirar o cachorro'.
\end{abstract}

Sendo o cachorro viciado, a corda, as correntes, etc, só impedem que ele ataque à criação enquanto elas o mantiverem preso. Liberto, o cão pegaria novamente as ovelhas quando a oportunidade aparecesse.

Os dois moradores, ao narrarem a história do cachorro de Naldo, mencionam duas possibilidades convencionais de reparação, que foram apresentadas por Renato: ou o sacrifício do cão, ou o pagamento da criação morta. Naldo não optou por nenhuma das duas, mas, em um momento anterior, por amarrar o bicho e, depois da visita de Renato, por dar o animal para alguém. Nenhuma dessas soluções impediu que o cachorro continuasse atacando rebanhos, de modo que o evento aqui escolhido tem certa exemplaridade. A solução definitiva, como diria um irmão de Naldo ao ouvir um relato

\footnotetext{
${ }^{11}$ Sobre a centralidade dessa circulação de narrativas nos voltaremos adiante.
} 
similar em outra ocasião, "É matar", pois “cachorro que pega criação, ele não deixa nunca".

Por isso, muitos sertanejos dizem que, ao presenciar um cachorro atacando criação, independentemente de quem sejam os donos de ambos os animais, a atitude apropriada é matar o cão: "Pois eu mato o meu e bonito mermo eu mato é o dos outros", dizia um deles. Outros, como o pai de Naldo, ressaltavam o que os criadores deveriam fazer caso presenciassem um cachorro seu atacando ovelhas: "Eu possuindo um cachorro, ele pegando criação, eu fico com raiva é se o dono da criação não matar logo. Não tem conversa, não!", com o que um criador, que teve o rebanho atacado ainda naquele dia por um cachorro desconhecido, concordou.

O que os sertanejos parecem esperar, nesse caso, é uma espécie de reciprocidade do tratamento. Se os rebanhos são de propriedade individual ou familiar, há certa ordem de cuidado e de governo dessas populações animais que diz respeito a uma coletividade humana mais ampla. Um morador - recontando-me uma conversa que tivera com o patrão sobre os seus cachorros, que poucos dias antes haviam atacado o carneiro de um vizinho muito seu amigo - exemplificaria isso do seguinte modo: "se eu criar um cachorro e ele pegar uma ovelha, [...] eu mato; agora, se um cachorro também pegar uma ovelha minha, eu mato, pode ser de quem for. [...] Matei um meu porque pegou dos outros e [se] um dos outros pegar uma minha eu vou deixar ele vivo?!" Embora alguns confessem matar com tristeza e dó os próprios cachorros, ao fazê-lo eles estarão se livrando de acusações futuras que podem lhes ser dirigidas e também da obrigação de indenizar as ovelhas mortas e outras que, eventualmente, surjam no futuro.

Por vezes, na impossibilidade de comprovar a culpa de determinado cachorro, os criadores optam por uma estratégia muito mais criticável e arriscada: o envenenamento dos cães. Os criadores atingidos preparam as bolas - sebo ou carne misturados com veneno para ratos e, às vezes, cacos de vidro -, que serão lançadas para os cachorros. Se a estratégia é moralmente controversa para os interlocutores, é porque as bolas podem vitimar toda espécie de animais domésticos que as ingerirem - há relatos sobre porcos e gatos que o fizeram - e também cães reconhecidos como sem culpa, que não devem, atraídos pela armadilha. Mas o caráter controverso (e arriscado) também se deve ao deslocamento daquele que lança as bolas até as cercanias da casa ou do sítio em que vivem os cachorros. Pedro Sobrinho confessa ter cogitado lançar as bolas para os cachorros de Naldo, mas os riscos da invasão da casa dos outros em plena madrugada o fizeram mudar de ideia. 
Se o ataque dos cães - à noite, geralmente - é, na maioria das vezes, imperceptível até que amanheça o dia, esse também parece ser o caso com o uso das bolas. E se os donos do rebanho atacado, sem evidências consistentes, só poderão suspeitar do(s) seu(s) autor(es) canino(s), o mesmo também ocorre com os donos dos cachorros vitimados pelas bolas. Na impossibilidade de provar que um determinado cachorro foi o autor do ataque ou prevendo uma resistência por parte do(s) dono(s), o envenenamento na surdina se assemelha ao ato que combate: subterrâneo, silencioso e moralmente delicado, é difícil comprovar a sua autoria. E nisso ele se distancia da morte dos cães (sejam eles do próprio autor ou de outrem) que tenham, comprovadamente, pego criação, muitas vezes tornada pública. Ao publicizar a morte desses cães, o dono do animal ou o criador atacado afirmam, frente aos outros, o seu valor.

No Sertão dos Inhamuns, os cachorros e os outros animais, sejam eles domésticos ou não, são ditos sem entendimento, ao contrário dos humanos. Eles são bichos brutos. Porque "as coisas de Deus são muito bem feitas", todo animal tem uma porção específica de entendimento voltada para as suas circunstâncias: é a defesa. Defesa descreve as características físicas e potências próprias a cada espécie animal, de forma que pode se tratar, de fato, de uma "defesa" contra algo ou alguém. Tendo garras muito fortes, mas sendo lerdo, o tamanduá deita-se de costas no chão e abre os braços esperando ser atacado pelo agressor. Quando a ameaça se aproxima, o tamanduá fecha as garras sobre ela em um abraço que causa uma dor cruciante. Do mesmo modo, a onça não tem o faro tão apurado quanto o dos cães, mas é muito ágil e se move sobre as folhas secas da caatinga sem fazer qualquer barulho.

Se a ausência de entendimento marca o status do bruto, também é esse o caso com as crianças e recém-nascidos, mas, nesse caso, o amadurecimento social e cognitivo delas equivale a um desenvolvimento da capacidade de entender. Como seres sem entendimento, crianças e brutos não merecem muitos sofrimentos que lhes são infligidos. Foi o que disse uma interlocutora, frente aos anos seguidos de seca, ao pedir chuva a Deus não por ela, pelo esposo ou pelo filho já adulto, que não tinham merecimento da piedade divina, mas pelas crianças e pelos bichim, entendidos como inocentes.

Como observado por Mayblin (2010), o desenvolvimento do entendimento das crianças, concomitante ao seu crescimento e amadurecimento, traz consigo a perda da sua inocência, a entrada em um mundo de pecado a partir do momento em que não se tem mais a ignorância sobre as coisas do mundo. Por serem inocentes, as crianças não 
distanciam o bem do mal, e espera-se que, com o tempo, elas aprendam a diferenciar condutas socialmente recomendáveis das condutas desaprovadas.

Entendimento, portanto, não é sinônimo de conhecimento racional e não descreve a capacidade de pensar racionalmente. Trata-se, sobretudo, da consciência do lugar que se ocupa em um mundo habitado por outros seres (sejam eles humanos ou não) e de um consequente e contínuo exercício de reflexão ética necessário para se viver com os outros. Se o entendimento é parte da vida humana adulta, há quem o tenha pouco e há quem o tenha em boa medida.

Assim, se um burro dá um coice em que se aproximou rapidamente dele ou se um cachorro é agressivo com seu dono quando ele tão somente tentava curar uma ferida sua, é porque eles, enquanto brutos, não entendem as consequências dos seus atos, é da sua defesa agir da forma que fazem. De outro lado, não se pode desconsiderar o fato de que há indivíduos animais com personalidades que ou vão contra as expectativas humanas, ou as superam. Pedro Sobrinho, por exemplo, me descrevia impressionado como um dos cachorros do filho era capaz de encontrar no mato uma pedra que o dono tivesse lançado e trazê-la de volta com a boca. Outro interlocutor debochava do caráter medroso de um cachorro que, caçando, latia assustado contra as raízes de uma árvore. Muitos animais desenvolvem tal capacidade de se comportar como humanos (expressando afeto desmedido pelos seus donos ou uma inteligência insuspeita) que "só não falam porque Deus não dá o consentimento". De modo parecido, há humanos que agem como brutos, que em sua forma de se comportar e de lidar com os outros assumem qualidades próprias dos animais.

Quando tais idiossincrasias se tornam regulares, os animais podem ser ditos, por exemplo, ladrões (quando comem de pastos e roças onde não poderiam), velhacos (quando, repetidamente, não se dobram aos desígnios humanos), cabreiros (quando são desconfiados e não se deixam seduzir pelas ações humanas dirigidas a eles), opiniosos (quando são cheios de opiniões, atitudes, inusitadas e firmes), famosos (quando sua beleza física e constituição corporal são notáveis, dignas de fama) e viciados (quando uma atitude vista como inapropriada ou contraproducente é recorrente).

O caso dos cachorros viciados em atacar criação, portanto, é uma espécie de situação limite em que a recalcitrância dos brutos abala (e mesmo questiona) a inocência própria aos animais e as suposições humanas sobre eles ${ }^{12}$. A regularidade da

${ }^{12}$ Essa concepção ambígua do estatuto animal se deixa ver, por exemplo, em algumas passagens do romance Moby Dick, de Herman Melville. Espantado com o desejo do capitão do navio Pequod de se 
ação danosa é vista como uma falha de caráter de que não poderão se livrar por não terem entendimento ${ }^{13}$. Nessa situação limite, a pena que muitos sertanejos sentem ao matar animais para fins que não a alimentação está, em muitos casos, ausente. A morte do animal aparece, portanto, como uma resposta extrema a uma situação igualmente extrema.

\section{Das reflexões éticas sobre os cães e seus ataques}

Na convivência entre os moradores do Sertão dos Inhamuns e do interior de Pinhão, o cuidado com a própria criação e com a dos outros surge como uma das mais importantes questões práticas, de modo que as pessoas estão sempre observando os deslocamentos dos seus animais, inclusive dos cães. Essas formas de observação assemelham-se ao que Comerford (2014) nomeia "sistemática do vigiar e do narrar", ou seja, são formas de olhar inseparáveis de formas de falar, de recriar em narrativas o que se viu e se sabe ${ }^{14}$. Os movimentos de pessoas e de animais se tornam tema de avaliação, produção de reputações e podem acarretar em tensões entre quem vive nessas localidades rurais. As duas narrativas acima citadas sobre os cachorros de Naldo exemplificam isso. Nesse caso específico, chama atenção que os dois relatos tenham uma estrutura basicamente similar e apresentem as falas dos seus protagonistas recurso narrativo, aliás, muito comum ali. Não por acaso, Sobrinho e o outro vizinho teceram julgamentos morais sobre as atitudes de Naldo: o primeiro o chamaria de covarde por não ter assumido a culpa dos seus cães; o segundo caracterizaria o ato (ou, antes, a ausência dele) como triste, dizendo em seguida que aquilo não se fazia nem com um inimigo, muito menos com um amigo. Tanto a criação quanto os cachorros tomam parte, por conseguinte, na "sociabilidade agonística" (Comerford, 2003),

vingar da Baleia Branca, o marinheiro Starbuck, defendendo a inocência do animal e a irracionalidade do seu superior, grita: "'Vingança sobre uma besta que não fala [...], que te atacou simplesmente por um instinto cego! Loucura! Sentir ódio de uma criatura muda, capitão Ahab, me parece uma blasfêmia!" (Melville, 2008: 183). Em outra passagem, Ishmael, o narrador, questiona a suposta inocência de Moby Dick ao destacar a aparente intencionalidade do animal: "de tal forma se apresentava a premeditação infernal de ferocidade da baleia branca que cada mutilação ou morte causada não era de todo pensada como ataque de um agente irracional" [grifo nosso] (ibid: 206).

${ }^{13} \mathrm{O}$ vício, aliás, é visto como problemático e difícil de ser largado até mesmo pelos humanos. Existe um adágio sertanejo sobre o vício que acaba por igualar humanos e animais, destacando tanto a reincidência como um provável fim amargo para ambos: "Homem que bebe e joga/ Mulher que errou [ou "deu"] uma vez/ Cachorro que pega bode/ Coitadinho desses três" (Lamartine, 1980: 218).

14 Ao evidenciar esse vínculo entre mobilidade e recriação narrativa, acreditamos que o que está em jogo na socialidade de Pinhão e dos Inhamuns é uma relação indissociável entre movimento, conhecimento e descrição, para usar os termos de Ingold (2011). 
dinâmica que conforma os modos de apresentação, confrontação e tensionamento entre as famílias que habitam esses territórios.

Muitas vezes, quando uma pessoa encontra um animal de criação perdido, ela cuida dele até que seu dono apareça ou busca levá-lo até ele. Esse tipo de ato gera laços de respeito mútuo entre aqueles que vivem nessas localidades. Em contrapartida, quando os animais de determinado dono entram no terreno de outra pessoa e lá causam estragos, a boa convivência entre tais sujeitos pode se estremecer, e o dono do bicho insolente deverá, de algum modo, responder pelos danos causados por seu animal.

Como ressalta Andriolli (2011), ao "mexer com a criação", os criadores não estão interessados somente no valor econômico de seus bichos, mas tecem afetos para com eles, através dos próprios cuidados necessários à manutenção e reprodução das reses. Os cães, desse modo, inserem-se nesse circuito de afetividade mais ampla e suas ações são tidas como de responsabilidade de seus donos, que devem de algum modo se manifestar frente aos danos causados. Isso faz com que, em ações e expectativas como essas, os animais de criação e os cachorros se apresentem como extensões de humanos, de forma que, tal qual observado por Pereira (2015: 82), sua circulação é também “a circulação de pessoas estendidas". No limite, o (des)controle sobre os próprios animais acaba sendo uma forma de demonstrar "respeito" ou "falta de respeito" pelos outros (Comerford, 2014: 115).

$\mathrm{Na}$ trama da responsabilização pelo dano, há algo parecido ao que Leal (2014) assinala sobre a produção de reputações e de prestígio entre os criadores de gado de elite e o próprio gado, em que as influências de mão dupla entre produtor e criação fazem com que as reses corporifiquem o saber dos seus criadores e os seus nomes, enquanto os criadores são reconhecidos e prestigiados pelas qualidades de seus animais. Essas influências de mão dupla são um assunto recorrentemente problematizado nas narrativas sobre os ataques protagonizados pelos cachorros, em que os donos negligentes são questionados e mal-falados, tornando-se reconhecidos por uma coletividade mais ampla, a partir do espraiamento do assunto, como pessoas desrespeitosas e não confiáveis, de maneira que as ações dos seus animais atingem diretamente suas reputações. Os donos são tidos como os responsáveis por encontrar uma solução para acabar com o mau comportamento de seus bichos, aqueles que teriam a legitimidade para matá-los (solução fatídica, porém tida como a única possível) e que deveriam fazê-lo frente aos estragos causados. 
Na medida em que as atitudes dos humanos, dos animais de criação e dos cães produzem reverberações no estatuto de um e de outro, os laços entre eles conformam um tecido moral interespecífico. Nele, o que está em jogo é não somente a relação de propriedade, mas uma forma de pertencimento e mútua implicação ética - já que as avaliações sobre os atos dos bichos recaem diretamente sobre seus donos. Cães e outros animais tomam parte na ética dos nossos interlocutores tanto porque a partir das suas ações "promovem verdadeiros vínculos" (Pereira, 2015: 82) quanto porque por meio delas os animais podem desfazer esses laços e arranhar a reputação dos donos (que podem ser ditos irresponsáveis ou pusilânimes quanto a eles). Como observado por um morador dos Inhamuns, manter consigo um cachorro que atacou uma ovelha acarreta um problema: “[...] às vezes, vem um cachorro do [sítio] Alto Belo, do [sítio] Angico, mas só paga o meu, porque o meu tem a fama”. É por ter a fama de pegar criação que as suspeitas em caso de ataque se dirigiriam a tal cão e ao seu dono. Tanto a fama quanto o vício são produto da percepção da regularidade de uma certa conduta. Como afirma Marques (2002: 104), a fama é uma espécie de imagem estereotipada de determinados sujeitos, que contribui para a produção de expectativas em torno de seu comportamento, "no sentido de suas ações corresponderem à fama que possuem". É a partir das interações com os outros que humanos e animais são "modelados e publicamente conhecidos como personagens morais", de sorte que tal imagem se torna decisiva no julgamento e interpretação de ações subsequentes (Keane, 2010: 75).

O estatuto dos cachorros, tal como refletem nossos interlocutores, não é fixo, porém modelado contingencialmente, através das relações e dos atos para com os humanos e os outros bichos que habitam os mesmos ambientes, sejam eles de criação ou animais selvagens. Os cães, desse modo, podem ser tidos como bons companheiros, bons pastores, bons cuidadores da casa, bons caçadores. Porém, se começam a atacar a criação de seus donos ou, pior, dos vizinhos, os cães tornam-se problemáticos, mais ainda porque se reconhece que, uma vez que começam a matar os outros bichos, eles não deixam mais de fazê-lo.

Em seu manifesto sobre as espécies companheiras, Haraway (2003) discute o talento do cão, que emerge a partir do trabalho relacional do treinamento, no curso do qual o animal e seu dono podem descobrir uma certa satisfação de viver juntos. Em sua relação, cães e humanos constroem direitos uns sobre os outros, como o direito de demandar respeito, atenção e resposta. Nos termos da autora, esses direitos são enraizados na posse recíproca, de modo que suas demandas mudam as vidas de ambas 
as partes. Para nossos interlocutores, essa também é uma questão fundamental. Ao serem tratados, ensinados e cuidados enquanto acompanham seus donos nas andanças pelo terreno e para além dele, os cachorros também são tidos como seres que aprendem a ser de determinadas maneiras, a depender de como os donos se relacionam com eles. Nos Inhamuns, por exemplo, diz-se que a repreensão imediata do cachorro quando, ainda pequeno, ele começa a estranhar a criação pode reverter a tendência a atacá-la. Não havendo tal atitude por parte do dono, o cão já se vicia. Em Pinhão, também acredita-se que é preciso ensinar o cachorro, desde pequeno, a ficar perto da criação. Entretanto, em ambas as localidades as pessoas argumentam que caso o cão possua, em si, uma inclinação a atacar os rebanhos, não há o que ser feito. Nas áreas de faxinal, fala-se que essa é a natureza do bicho, algo que faz parte dele e que nem sempre o ensinamento do dono é forte o suficiente para domesticar.

Por outro lado, o cachorro pode ser visto, em princípio, como ser que não dá certo junto com a criação, como disse Ângela, em Pinhão. Isso, porém, não fazia com que Ângela deixasse de reconhecer que certos cachorros, quando bem ensinados, conseguem conviver harmonicamente com os outros animais do terreno, e que é importante ter um cão bravo para cuidar da casa. Nos Inhamuns, por sua vez, é comum marcar diferenças individuais entre os animais: há cães que passam por um rebanho de ovelhas e nada fazem, enquanto há outros que as estranham, podendo atacá-las. Mas, para além disso, os sertanejos costumam dizer que "não se pode pôr a mão no fogo por cachorro": o impulso predatório pode se revelar de um dia para outro.

Tomada por nossos interlocutores como hábito adquirido, a atitude dos cachorros de atacar a criação é apresentada de diferentes maneiras nos locais onde realizamos nossos trabalhos: em Pinhão, diz-se que os cachorros aprendem a pular na criação, enquanto nos Inhamuns, fala-se que os cachorros se viciam no sangue dos outros bichos. São hábitos perniciosos que eles desenvolvem e que não foram transmitidos por seus donos, aos quais os cães escapam do controle. No caso de terem sido ensinados a caçar, os cachorros que matam criação em Pinhão são tomados como inocentes, que agem de tal maneira porque seus donos assim os fizeram ser. Além disso, lá o cachorro é condenado se foi por conta própria atrás dos animais alheios ou pertencentes ao mesmo terreno a ele relacionado. No entanto, quando pula em porcos forasteiros que adentraram as cercas do terreno, não é o cachorro que é considerado como propagador de danos, e sim os porcos que foram parar nas terras dos outros. Nos Inhamuns, a noção de inocência é, mais propriamente, uma qualidade que seria fundante 
e característica da própria condição animal. O caso dos cães viciados é, como observado, uma situação em que tal inocência é problematizada eticamente, de forma que o dilema colocado pelo ataque não se refere unicamente a forma apropriada de lidar com os outros humanos e com seus rebanhos, mas também com o próprio cão que ao pegar a criação apresentou uma falha moral aparentemente sem possibilidade de correção.

Beviláqua (2016) reflete sobre a questão do "dano", tal como formulado em diferentes legislações e processos jurídicos, no Brasil e na Inglaterra, em casos de cães que atacam humanos. A autora observa como, no caso brasileiro, a ênfase jurídica na responsabilização do dono, que mantém um animal feroz, afeta os modos como os animais existem no direito, gerando um apagamento de sua ação e de sua singularidade, e tomando-os simplesmente como possíveis causadores de danos. O que os moradores do Sertão dos Inhamuns e do interior de Pinhão demonstram, em suas avaliações sobre os cães é que, apesar das considerações sobre os danos serem sempre levantadas quando ocorrem ataques à criação, os cachorros são parte ativa nessas tramas, sendo considerados em sua singularidade e liberdade. Os donos dos animais viciados, caçadores e "sem-vergonhas" também levam em conta as particularidades de seus bichos e de seus afetos para com eles. Por isso, o dano é uma linguagem que moraliza certos acontecimentos e que dá materialidade à perda, mas que jamais é o resumo da ópera. Em nossas pesquisas, tornou-se claro que as querelas não são conduzidas somente nesses termos e que levar adiante um processo de pagamento de danos no âmbito jurídico é muito mais uma ameaça ou uma possibilidade a ser considerada, do que algo efetivamente realizado ${ }^{15}$.

Dentre as problematizações realizadas pelas pessoas que sofreram perdas devido ao ataque de cães, destaca-se o reconhecimento de que os animais escapam ao controle humano, tendo seus próprios modos de ser e de agir. A questão da liberdade ganha importância na reflexão sobre as ações caninas e as respostas humanas frente a elas, porque permite dar conta da sua autonomia de vontade e grande capacidade de movimento. Se os donos esperam iniciativa e mesmo agressividade dos cães em uma série de atividades (o pastoreio dos animais, a proteção da casa, a caça a animais

\footnotetext{
${ }^{15}$ Notamos, nesse sentido, que tanto em Pinhão quanto nos Inhamuns, pagar o dano é uma convenção que é considerada, mas que não costuma ser realmente acionada. Por enquanto, não soubemos de alguém que efetivamente pagou o dano, ou que levou à delegacia esses conflitos com cachorros e foi bem sucedido por essas que seriam as vias mais "oficiais" de lidar com o assunto. A ameaça de formalizar o ocorrido na delegacia, no fórum - i.e., frente a alguma autoridade -, entretanto, pode ser suficiente para convencer um dono hesitante a se desfazer do seu animal.
} 
silvestres), também necessitam desenvolver mecanismos para governar tal liberdade e, mais amplamente, o próprio estatuto animal. Nem sempre isso será possível, e nesse sentido, as noções de natureza e vício emergem como fundamentais nas reflexões sobre a liberdade canina.

A natureza e o vício são termos por meio dos quais os nossos interlocutores elaboram suas compreensões sobre as ações dos cachorros, sobre as formas com que eles mesmos cultivam a sua liberdade e suas práticas em relação a si mesmo e aos outros - sejam humanos ou não. A natureza é trabalhada na relação intersubjetiva entre o dono e o seu cão, mas ainda assim, não há garantias de que a "sem-vergonhice" mantenha-se controlada. Por sua vez, os moradores de Catarina demonstram desconfiança em relação aos cães, que podem se viciar no sangue da criação, a ponto de impossibilitar a convivência com esses seres e com os humanos. Os atos dos cães, fomentados por natureza ou vício, revelam o poder que eles exercem sobre os outros, os modos com que produzem, deslocam e tensionam as tramas da vida social nas localidades em que habitam.

O imperativo da morte do cão nos dois contextos etnográficos que discutimos, e a relativa aceitação que os donos têm sobre o destino dos seus animais frente às evidências do ataque, demonstram uma ética ordinária do pastoreio, certas expectativas quanto às ações humanas e animais e mesmo um vocabulário por meio do qual expressá-las. Para além disso, evidenciam uma reflexão sobre o estatuto do animal e a responsabilidade humana sobre ele. Em Pinhão, isso fica claro na distância entre o cachorro inocente e o cachorro "sem-vergonha": no primeiro caso, a responsabilidade seria mais propriamente do dono, que, treinando-o como caçador, abriu margem para que atacasse a criação; no segundo, a autonomia de vontade canina é a responsável pelo ataque. Entretanto, se, em um caso, o "sem-vergonha" é o dono e, no outro, o cão, a punição vista como eficaz é a mesma: a morte do animal. No sacrifício, a punição é dirigida diretamente ao animal; no ressarcimento pelos danos causados, a punição recai sobre o dono. Em razão da expectativa de que o cão pule sobre ou pegue a criação outras vezes, a morte do animal acaba sendo a solução mais recomendada e menos onerosa para o dono.

Ainda assim, a morte do cachorro, quando realizada por aquele que sofreu o dano, é tida como uma forma de punir também o seu dono, o qual pode inclusive vir a questionar tal atitude, levando a novos desentendimentos e confusões entre essas pessoas que moram próximas umas das outras. Por isso mesmo, alguns de nossos 
interlocutores optam por matar os cachorros danosos às escondidas, envenenando-os e enterrando-os dentro de seus próprios terrenos, sobre os quais possuem autoridade e liberdade plena.

Essas ações também são problematizadas nas narrativas das pessoas, que buscam sempre justificar o que as leva a tomar tal atitude e a ponderar a culpa/inocência dos cães, tanto quanto os afetos e perdas sofridos frente aos ataques. Os cachorros, nessas narrativas, revelam-se como animais traiçoeiros e queridos, como seres cuja falta será mais ou menos sentida, e cuja morte, nos casos em que não é realizada pelo próprio dono, sempre pode gerar novas reclamações e conflitos. Ao mesmo tempo, muitos donos - como Naldo, por exemplo - hesitam em dar fim aos seus cães. É esse o tipo de atitude que faz com que os Miller, em Pinhão, acreditem ser melhor agirem por si mesmos, pois os donos dos cachorros jamais pagam o dano e muitas vezes não se livram dos seus animais contraventores. Mas se matar o cachorro é o certo, os Miller, de Pinhão, revelam que não é bom falar sobre isso para os outros, pois o dono muitas vezes não aceita que seu querido bicho tenha sido morto por outra pessoa - e isso mesmo que seja claro que o cão tenha causado enormes danos. Por isso não se mata um cachorro de qualquer jeito, e nem se fala sobre isso de qualquer forma e para qualquer um.

\section{Conclusão: uma comunidade moral interespecífica}

Há duas questões relacionadas sobre as quais tratamos na discussão precedente que julgamos importante explorar na conclusão deste artigo. A primeira delas, anunciada no final da sessão anterior, diz respeito à relação entre ética, linguagem e conflito. A segunda, que percorre todo o texto, diz respeito à vida coletiva em tais localidades rurais.

Tanto em Pinhão quanto nos Inhamuns, as narrativas, as fofocas e os comentários aparentemente mais descompromissados tecem uma "malha de conversas" (Comerford, 2014: 115) e têm papel fundamental no andamento dos conflitos e na formulação de julgamentos sobre os envolvidos ${ }^{16}$, sejam eles humanos ou não. Por meio dessas formas de expressão verbal, "O público se apropria dos conflitos e os torna matéria prima da construção de um campo de comunicação e de uma comunidade moral" (Marques, Comerford, Chaves, 2007: 37).

$16 \mathrm{O}$ que deve ser entendido também como uma forma de conhecimento extremamente eficaz empregada por nossos interlocutores. 
A fala e a narrativa, portanto, não devem ser entendidas como acessórios à ação ou tão somente como um conjunto de representações sobre os fatos narrados, mas como uma forma de ação em si (Briggs, 1996; Lambek, 2010). O evento narrativo vai além da descrição dos fatos a que se reporta, na medida em que (1) o narrador apresenta suas avaliações sobre tais fatos e as pessoas envolvidas e (2) busca influenciar a compreensão da audiência sobre o evento narrado. Tal audiência, contudo, não é inerte, pois a forma e o conteúdo da fala do orador são continuamente moldados por ela (Duranti, 1986). Em resposta, tais co-participantes podem trazer certos fatos à tona desconhecidos ou esquecidos pelo narrador - ao tecer comentários sobre o que foi narrado ou ao encadear àquela outras narrativas sobre eventos similares. Dessa forma, as narrativas não são meros reflexos de ações efetivas, que se desenvolvem de modo exterior a elas, mas sim oportunidades e meios para realizar uma série de ações (Brenneis, 1996): elas podem ser instrumentos para obscurecer, confundir, explorar, etc, o que ocorreu, de forma a manter a coerência e a compreensão dos eventos narrados em aberto (Bauman, 1986).

Falar sobre os cachorros que atacam criação, lembrar de eventos ocorridos e descrever as atitudes dos donos produz conhecimento, orienta outras ações, faz ou desfaz reputações, dota certos lugares (sítios, vizinhanças, roças, pastos, etc) em que os eventos narrados e narrativos ocorreram de carga moral. O interesse sobre esse casos é coletivo porque o cão que hoje ataca o rebanho de alguém pode fazer em breve o mesmo com o meu, de um parente ou de um vizinho.

Assim, cães, porcos, ovelhas, humanos e outros animais integram uma mesma comunidade moral, mas de caráter interespecífico. Mais do que animais "domésticos" (no sentido de serem "de alguém") ou de criação, eles são animais "públicos" (no sentido da atenção a eles dirigida e dos desdobramentos das suas ações). Face ao que chamamos aqui de ética ordinária do pastoreio, parece-nos que a noção de "comunidade moral" (Bailey, 1971) é útil para pensar sobre a vida coletiva em tais localidades rurais.

O uso de "comunidade", contudo, não deve ser entendido em uma chave geográfica ou mesmo como um substituto aos conceito de sociedade e de cultura, pois o que está em jogo é uma forma de interação social. "Comunidade moral" também visa dar conta, descritivamente, de um "fundo comum de conhecimento" (Bailey, 1971: 4), em constante atualização, sobre outras pessoas e coletividades familiares, as reputações individuais e familiares assim como do estado das relações sociais (Comerford, 2003, 
2014). Aquela "malha de conversas" e a recriação narrativa a que nos referimos acima se mostram fundamentais, portanto, nessa forma de sociação.

Face ao que foi discutido nas seções anteriores sobre os ataques dos cães aos rebanhos (uma situação que guarda certa exemplaridade), podemos afirmar que os animais de criação têm papel decisivo na modulação de tais relações sociais, e daí falar em termos de uma comunidade moral interespecífica. Não se trata, contudo, de centrar a descrição exclusivamente nas "representações" sobre os animais, embora elas também sejam instrutivas. Defendemos que em tais localidades rurais cães, ovelhas, porcos e outros animais são agentes com papel decisivo na vida social e assim percebidos pelos nossos interlocutores; mas também que tais seres não humanos partilham uma condição ética com os seres humanos.

As formas apropriadas de comportamento para os animais podem ser internalizadas, inscritas em seus corpos, a partir da ação humana. Nem todos os cães atacam rebanhos, nem todos os porcos furam cercas e nem todos os cavalos derrubam quem os monta. A possibilidade de correção de uma conduta desaprovada está aberta, portanto, para muitos desses animais, que são ensinados a se comportar de determinadas maneiras, mas que, no engajamento, também ensinam os humanos a lidarem com eles 17. Veja-se na seção anterior, por exemplo, a menção à possibilidade de refrear o impulso inicial dos cães de pegarem criação por meio de repreensões físicas e verbais.

Entretanto, assim como nem todos os humanos são influenciados com sucesso a abandonarem condutas e ações socialmente desaprováveis, também é esse o caso com alguns cães, que tendo se viciado ou aprendido a pular sobre as ovelhas não deixarão de fazê-lo. As idiossincrasias de tais seres colocam problemas para concepções dos animais que os tomam como "autômatos biológicos", que não levam em conta "o comportamento individual imprevisível de cada indivíduo, assim como sua astúcia e sua capacidade de improviso" (Sussekind, 2014: 191).

Falamos, portanto, em termos de uma comunidade moral interespecífica para descrever essa forma de mútua implicação e coinfluência, o englobamento moral entre donos e seus animais de criação, que também são reputados e produtores de reputações. Um esforço nesse sentido, contudo, deve ir além da consideração dos animais apenas

\footnotetext{
17 Vinciane Despret (2004) abre possibilidades de análise ao chamar atenção para a "afinação [attunement]" entre os corpos humanos e animais, que afetam e são afetados. O processo de domesticação, portanto, é recíproco, transformando não só os animais, mas também os humanos que lidam com eles. As práticas antropo-zoo-genéticas engendram novos modos de comportamento e novas identidades para ambos, de forma que animal e humano "devém juntos [becoming together]".
} 
como bens incorporados ao patrimônio individual ou familiar, pois nos parece claro que, para nossos interlocutores, eles são e podem muito mais do que isso.

\section{Referências}

ALMEIDA, Alfredo Wagner Berno de, SOUZA, Roberto Martins de. Terras de faxinais. Manaus: Edições da Universidade do Estado do Amazonas, 2009.

ANDRIOLLI, Carmen Silvia. Sob as vestes de Sertão Veredas, os Gerais: "Mexer com criação" no Sertão do IBAMA. Tese (Doutorado em Ciências Sociais), Universidade Estadual de Campinas, Campinas, 2011.

BAUMAN, Richard. Story, performance and event: contextual studies of oral narrative. Cambridge: Cambridge University Press, 1986.

BAILEY, F.G. Gifts and Poison: the politics of reputation. Oxford: Basil Blackwell, 1971.

BEVILÁQUA, Ciméa. Direito(s) e agências não-humanas: como julgar os atos de um animal? In: BEVILÁQUA, Ciméa Barbato, VANDER VELDEN, Felipe. Parentes, vítimas, sujeitos: perspectivas antropológicas sobre relações entre humanos e animais. Curitiba: EdUFPR; São Carlos: EdUFSCar, 2016. p.375-405.

BRENNEIS, Donald. Telling troubles: narrative, conflict, and experience. In: BRIGGS, Charles L. (Ed.). Disorderly discourse: narrative, conflict and inequality. Oxford: Oxford University Press, 1996. p.41-52

BRIGGS, Charles L. Introduction. In: . (Ed.). Disorderly discourse: narrative, conflict and inequality. Oxford: Oxford University Press, 1996. p.1-40.

CHANDLER, Billy Jaynes. Os Feitosas e o sertão dos Inhamuns: a história de uma família e uma comunidade no Nordeste do Brasil - 1700-1930. Fortaleza: Edições UFC; Rio de Janeiro: Civilização Brasileira, 1980.

CHANG, Man Yu. Sistema Faxinal: uma forma de organização camponesa em desagregação no Centro-sul do Paraná. Londrina: IAPAR, 1988.

COMERFORD, John. Como uma Família: Sociabilidade, Territórios de Parentesco e Sindicalismo Rural. Rio de Janeiro: Relume-Dumará, 2003.

. Vigiar e narrar: sobre formas de observação, narração e julgamento de movimentações. Revista de Antropologia, São Paulo, v. 57, n.2, p. 107-142, 2014.

DAS, Veena. Ordinary Ethics. In: FASSIN, Didier (Ed.). A companion to moral Anthropology. Oxford: Willey-Blackwell, 2012. p.133-149.

DESPRET, Vinciane. The body we care for: figures of anthropo-zoo-genesis. Body \& Society, v.10, n.2-3, p.111-134, 2004.

DURANTI, Alessandro. The audience as co-author: an introduction. Text: an interdisciplinary journal for the study of discourse, v.6, n.3, p.239-247, 1986.

FOUCAULT, Michel. História da Sexualidade 2: O Uso dos Prazeres. São Paulo: Graal, 2010 [1984].

HARAWAY, Donna. The Companion Species Manifesto: Dogs, People, and Significant Otherness. Chicago: Prickly Paradigm Press, 2003.

INGOLD, Tim. Being alive: essays on movement, knowledge and description. London, New York: Routledge, 2011.

KEANE, Webb. Minds, surfaces, and reasons in the Anthropology of Ethics. In: LAMBEK, Michael. (Ed.). Ordinary ethics: anthropology, language and action. New York: Fordham University Press, 2010. p.64-83.

LAIDLAW, James. For an anthropology of ethics and freedom. Journal of the Royal Anthropological Institute, v.8, n.2, p.311-332, 2002.

LAIDLAW, James. Foucault's genealogy and the undefined work of freedom. In: The subject of virtue: an anthropology of ethics and freedom. Cambridge: Cambridge University Press, 2014. p.92-137.

LAMARTINE, Oswaldo. A caça nos sertões do Seridó. In: Sertões do Seridó. Brasília: 1980. p.183-219. 
LAMBEK, Michael. Introduction. In: (Ed.). Ordinary ethics: anthropology, language and action. New York: Fordham University Press, 2010. p.1-36.

The ethical condition: essays on action, person and value. Chicago: The University of Chicago Press, 2015.

LEAL, Natacha Simei. Nome aos bois: Zebus e zebuzeiros em uma pecuária brasileira de elite. Tese (Doutorado em Antropologia Social). Universidade de São Paulo, São Paulo, 2014.

MARQUES, Ana Claudia. Intrigas e questões: vingança de família e tramas sociais no sertão de Pernambuco. Relume Dumará: Rio de Janeiro, 2002.

MARQUES, Ana Claudia; COMERFORD, John; CHAVES, Christine. Traições, intrigas, fofocas, vinganças: notas para uma abordagem etnográfica do conflito. In: MARQUES, Ana Claudia (org.). Conflitos, política e relações pessoais. Fortaleza: UFC/FUNCAP/CNPq-Pronex; Campinas: Pontes, 2007. p.27-55.

MAYBLIN, Maya. Gender, catholicism and morality in Brazil: virtuous husbands, powerful wives. New York: Palgrave Macmillan, 2010.

MELVILLE, Herman. Moby Dick. São Paulo: Cosac Naify, 2008.

PALMEIRA, Moacir. Casa e trabalho: notas sobre as relações sociais na plantation tradicional, Revista de Ciências Sociais do Centro de Estudos Noel Nutels, n.2, nov.1977, p.103-114.

PEREIRA, Luzimar Paulo. O movimento dos bichos: notas etnográficas sobre animais, seres humanos e espaços em Urucuia, MG. Ruris, v.9, n.1, p.63-84, 2015.

PORTO, Liliana. Uma reflexão sobre os faxinais: meio-ambiente, sistema produtivo, identidades políticas, formas tradicionais de ser e de viver. In: PORTO, Liliana, SALLES, Jefferson de Oliveira, MARQUES, Sônia M. dos Santos (Orgs). Memórias dos Povos do Campo no Paraná - Centro-Sul. Curitiba: ITCG, 2013. p.59-77.

SOUZA, Roberto Martins de. "Na luta pela terra, nascemos faxinalenses": uma reinterpretação do campo intelectual de debates sobre os faxinais. Tese (Doutorado em Sociologia). Universidade Federal do Paraná, Curitiba, 2010.

SUSSEKIND, Felipe. $O$ rastro da onça: relações entre humanos e animais no Pantanal. Rio de Janeiro: 7Letras, 2014.

VANDER VELDEN, Felipe. Inquietas companhias: sobre os animais de criação entre os Karitiana. São Paulo: Alameda, 2012.

Recebido em: 29/10/2016.

Aprovado em: 29/11/2016. 